\title{
Psychological distress in patients listed for liver transplantation ${ }^{1}$
}

\section{Distress psicológico em pacientes na lista de espera para transplante de fígado}

\author{
Patrícia Duarte Martins², Ajith Kumar Sankarankutty ${ }^{3}$, Orlando de Castro e Silva ${ }^{4}$, Ricardo Gorayeb \\ 1. Work perfomed in the Liver Transplantation Unit of Division of Gastroenterology of the Department of Surgery and Anatomy - Faculty \\ of Medicine of Ribeirão Preto - University of São Paulo (FMRP-USP), Brazil. \\ 2. Psychologist - Department of Neurology, Psychiatry and Medical Psychology (HCFMRP-USP), Brazil. \\ 3. PhD, Professor of Division of Gastroenterology of the Department of Surgery and Anatomy (FMRP-USP), Brazil. \\ 4. Full Professor and Head of Division of Gastroenterology of the Department of Surgery and Anatomy, (FMRP-USP), Brazil. \\ 5. Associate Professor of the Department of Neurology, Psychiatry and Medical Psychology (FMRP-USP), Brazil.
}

\begin{abstract}
Purpose: To assess the level of depression in patients listed for liver transplantation. Methods: Sixty-four adult patients, listed for liver transplantation, were submitted to psychological evaluation, including assessment of depression by means of the Beck Depression Inventory. Results: Twenty-two percent of the patients had mild/major depression. The group consisted mainly of male patients aged 47 on average, with a history of alcohol abuse and a Meld (Model for End-Liver Disease) value of 14.5. Patients that had been awaiting liver transplant longer presented less severe liver disease according to the Child-Pugh criteria. Conclusion: It is extremely important to assess psychological distress in patients listed for liver transplantation. An interdisciplinary approach is essential to improve the patients' quality of life both in the pre- and posttransplant periods.
\end{abstract}

Key words: Liver Transplantation. Psychology. Depression. Interview Psychological.

\section{RESUMO}

Objetivo: Avaliar o nível de depressão de doentes que aguardam em fila para transplante de fígado. Métodos: Sessenta e quatro pacientes adultos, com indicação para transplante de fígado, foram submetidos à avaliação psicológica, incluindo depressão, através do Beck Depression Inventory, após a inclusão em lista de espera. Resultados: Vinte e dois por cento dos pacientes apresentaram depressão moderada/grave. O perfil deste grupo foi caracterizado como sexo masculino, com idade média de 47 anos, presença de alcoolismo e Meld (Model for End-Liver Disease) de 14,5. Constatou-se que pacientes há mais tempo em lista apresentaram menor gravidade da doença hepática segundo a classificação de Child-Pugh. Conclusão: Ressalta-se a importância de avaliar o estado emocional de pacientes em fila de espera para transplante de fígado e da atuação interdisciplinar para melhoria da qualidade de vida dos pacientes, inclusive no pós-transplante.

Descritores: Transplante de Fígado. Psicologia. Depressão. Entrevista Psicológica.

\section{Introduction}

Liver cirrhosis affects more than half of the patients submitted to liver transplantation. These individuals live under lifethreatening conditions and their quality of life may be affected by the clinical outcome of the disease, the presence of medical complications, social life restrictions, and the need for the long-term use of drugs. All these factors have a profound impact on the patient's psychological condition, daily activities, and social development. These changes trigger important subjective difficulties for the patient that range from reorganization of the family dynamics to poor psychological support, all of which lead to symptoms related with different levels of anxiety, phobia, obsession, and depression ${ }^{1}$. In many cases, facing the diagnosis and obtaining information about the treatment can lead the patient to reflect on their being, life, death, values, among other issues. Psychological assistance in liver transplantation programmes may help the candidate deal with difficulties that may result in depression or even other psychiatric disorders. Besides the fact that the chronic disease is a causative agent of stress and can often lead to psychopathology, being listed for transplant may exacerbate such stress ${ }^{2}$. The moment a candidate is included in a transplant list may have positive or negative effects on the patient, depending on the individual. In some cases, being listed is an object of hope and allows psychic and social reorganization. In other cases, this fact may be seen as unfortunate evidence that the disease is progressing and, therefore, there is no other possibility of cure. Pretransplant psychiatric disorders may persist 
after the surgery and they are obviously related with noncompliance, especially in patients that had not had their depression treated before the transplantation ${ }^{3}$. Depression has been pointed out as one of the commonest clinical manifestations in patients submitted to different kinds of transplant. The impact of the psychological condition on the final outcome is not yet clear. Factors such as the patient's ability to discriminate between the positive and negative aspects of the transplant, their real expectations, coherent future plans, ability to react to stress and to cope with frustration seem to be related with good posttransplant outcome ${ }^{4}$. There is not an estimate of the incidence of mood changes, especially those concerned with depression, in patients listed for liver transplantation. International investigations ${ }^{5}$ including a larger number of patients report that $20 \%$ of the candidates listed for liver transplantation present adjustment disorders, $4.5 \%$ of which fulfill the criteria for major depression. To the best of our knowledge, there are no systematic clinical studies correlating depression, chronic liver disease, and liver transplantation in Brazil. According to the Handbook of International Disease Classification ${ }^{6}$, in typical episodes of depression (light, moderate or acute), the individual usually suffers from depressed humour, loss of interest and pleasure, reduced energy, all of which lead to increasing tiredness and decreased activity. Remarkable tiredness after light effort is common. Other symptoms include a) reduced concentration and attention; b) reduced self-esteem and self-confidence; feelings of guilty and worthlessness; d) miserable and pessimistic views of the future; e) self-punishment and suicidal ideas; f) broken sleep; g) reduced appetite. Major depression may be considered when the patient presents repeated episodes of depression. The aim of the present study is to carry out psychological assessment in patients listed for liver transplantation, as well as identify the incidence and the level of depression in such individuals.

\section{Methods}

- Sampling - Sixty-four patients listed for liver transplantation and being clinically followed by the Integrated Group for Liver Transplantation of HCFMRP / USP were included in the study. Inclusion criteria demanded that the patient should: a) be aged 19 and over; b) be literate enough to read and understand the questions; c) be included in the liver transplantation list of the Transplantation System of the Health Secretariat of the State of São Paulo; d) comply with and sign the Informed Consent Term.

- Procedures - After being listed, the patient was submitted to evaluation by means of a psychological interview, carried out as a routine procedure in the hospital. The candidate was then invited to take part in the study, independent of when he had been listed. The Beck Depression Inventory ${ }^{7}$ was used to diagnose depression. The original scale consists of 21 items, including symptoms and attitudes, whose intensity ranges between zero and three. The final score determines the severity of the depression according to the following levels: minimal, light, moderate, or major. The Child-Pugh and Meld criteria were used to evaluate the severity of the liver disease.

- Statistical analysis - Was carried out by means of the Non-Parametric Mann-Whitney Test, $\mathrm{c}^{2}$ Test and Kruskal-Wallis Test. The "post hoc" DUNN test was applied when there were statistical differences.

\section{Results}

Table 1 correlates demographic data with the level of depression in the individuals included in the present study. For statistical analysis purposes, patients with minimal/light depression and moderate/major depression were grouped together, and the two groups were then compared. The majority of the patients were male, married, and aged 40 and over. There was no statistically significant difference between the levels of depression when the demographic variables gender, marital status, and age were taken into account. Table 2 correlates clinical data with the level of depression in the patients included in this study. It also shows the number and percentage of patients with different diagnosis and their levels of depression. For comparison, we analyzed alcoholic liver cirrhosis (subgroup 1, 23 patients); viral liver cirrhosis (subgroup 2, 23 patients); and other liver pathologies (subgroup 3, 18 patients). There was no statistically significant difference between the levels of depression when the etiological variables were considered as described above. Also, the time elapsed since the candidate was listed for transplantation did not lead to statistically significant differences in the level of depression. The levels of depression were not statistically different when the Meld values were considered. However, it is noteworthy that moderate/ major depression was associated with a positive history of alcoholism in $50 \%$ of the cases. Table 3 contains data concerning the time elapsed since the patient was listed for liver transplantation and the severity of the disease, as measured by the Child-Pugh scale. Data from 59 patients were analyzed, and the five patients diagnosed with FAP were not included because this disease does not allow application of the Child-Pugh scale. Correlation between time elapsed since the patient was listed for transplantation and severity of the liver disease (ChildPugh) was inverse and statistically significant. The moment the Beck Depression Inventory was applied, patients that had been longer in the list presented ChildPugh "A"; i.e., they were clinically stable and assymptomatic. It is noteworthy that 12 out of the 19 patients with Child " $\mathrm{A}$ " had alcoholic liver cirrhosis. 
TABLE 1 - Correlation between demographic data and the level of depression in patients listed for liver transplantation

\begin{tabular}{|c|c|c|c|c|c|}
\hline \multirow[t]{2}{*}{ Depression } & \multicolumn{2}{|c|}{ Gender (\%) } & \multicolumn{2}{|c|}{ Marital Status (\%) } & \multirow[t]{2}{*}{ Mean age (years) } \\
\hline & M & $\mathrm{F}$ & Married & Single & \\
\hline Minimal/light & $36(78.3 \%)$ & $14(77.7 \%)$ & $40(80 \%)$ & $10(71.4 \%)$ & 47.7 \\
\hline Moderate/Major & $10(21.7 \%)$ & $4(22.2 \%)$ & $10(20 \%)$ & $4(28.6 \%)$ & 46.9 \\
\hline Total & $46(100 \%)$ & $18(100 \%)$ & $50(100 \%)$ & $14(100 \%)$ & \\
\hline
\end{tabular}

TABLE 2 - Clinical data and evaluation of depression in patients listed for liver transplantation

\begin{tabular}{lcccc}
\hline Etiology of the disease & \multicolumn{2}{c}{ Depression } & $\begin{array}{c}\text { Time in waitlist } \\
\text { (months) }\end{array}$ & $\begin{array}{c}\text { Meld } \\
\text { (score) }\end{array}$ \\
\cline { 2 - 3 } & Minimal/light & Moderate/major & & 14.06 \\
\hline Primary Biliary Cirrhosis & $2(4 \%)$ & - & 12 & 14.63 \\
Cryptogenic Cirrhosis & $7(14 \%)$ & $1(7.1 \%)$ & 7.75 & 14.71 \\
Viral Liver Cirrhosis & $18(36 \%)$ & $5(35.7 \%)$ & 8.56 & 14.22 \\
Alcoholic Liver Cirrhosis & $16(32 \%)$ & $7(50 \%)$ & 6.78 & 11.22 \\
Autoimmune Disease & $3(6 \%)$ & - & 10 & - \\
Familial Amyloidotic Polyneuropathy & $4(8 \%)$ & $1(7.1 \%)$ & 9.4 & \\
(FAP)* & & & & \\
\hline Total & $50(100 \%)$ & $14(100 \%)$ & & \\
\hline
\end{tabular}

*This category does not have compatible data for calculation of the level of severity of the disease by means of the Meld scale.

TABLE 3 - Correlation between the severity of the disease and the time elapsed since the patient was listed for liver transplantation.

\begin{tabular}{ccc}
\hline Number of patients & $\begin{array}{c}\text { Time } \\
\text { (months) }\end{array}$ & $\begin{array}{c}\text { Child-Pugh } \\
\text { (level) }\end{array}$ \\
\hline 19 & $11.73^{*}$ & A \\
29 & 6.55 & B \\
11 & 5.09 & C \\
\hline
\end{tabular}

$* \mathrm{p}<0.05$

\section{Discussion}

High incidence of depression has been found in liver transplantation candidates. Patients with depression had poorer perceived quality of life, poorer adaptative coping, and lower functional status than nondepressed patients ${ }^{8}$. Moreover, pretransplant survival was significantly lower in depressed patients than in nondepressed ones, showing that the early diagnosis and treatment of depression may lead to better clinical outcome in the pre- and post-transplant periods. In a study ${ }^{9}$ carried out with 112 patients with alcoholic liver cirrhosis, it was verified that $36 \%$ of the patients were depressed, while $12 \%$ had anxiety disorders before transplantation. Concerning depression, $70 \%$ of the recipient women were depressed, against $12 \%$ of the men. In the present study, most of the candidates were male $(71.9 \%)$ and, therefore, data related to depression shows a different proportion within the studied group. In a study ${ }^{10}$ conducted with liver transplant candidates submitted to assessment of depression, it was verified that moderate/major depression was associated with younger patients (mean age $=27)$ and with alcohol abuse $(53 \%)$. As for patients with viral etiology, $29 \%$ of them had moderate/major depression. In the present study, there was no statistically significant difference in the level of depression when the etiology of the disease was concerned. However, among the patients with moderate/ major depression, 50\% were diagnosed with alcoholism. A higher incidence of depression was also observed in liver disease induced by viral hepatitis B and C (35.7\%) and in patients with Cryptogenic Liver Cirrhosis and FAP $(14.2 \%)$. We also found an inverse correlation between the time elapsed since the patient was listed for transplantation and the severity of the disease (ChildPugh), which suggests that once an interdisciplinary approach is adopted with these patients, there is significant improvement in their psychological distress due to interruption of alcohol intake and consequent clinical stabilization. 


\section{Conclusion}

On the basis of the findings described above, we highlight the importance of the identification and treatment of negative psychological disorders, especially depression, in patients listed for liver transplant, especially in patients with cirrhosis due to alcohol.

\section{References}

1. De Bona M, Ponton P, Ermani M, Iemmolo RM, Feltrin A, Boccagni P, Gerunda G, Naccarato R, Rupolo G, Burra $\mathrm{P}$. The impact of liver disease and medical complications on quality of life and psychological distress before and after transplantation. J Hepatol. 2000; 33: 609-15.

2. Stilley CS, Miller DJ, Tarter RE. Measuring psychological distress in candidates for liver transplantation: a pilot study. J Clin Psychol. 1997; 53: 459-64.

3. Bunzel B, Laederach-Hofmann K. Solid organ transplantation: are there predictors for post transplant noncompliance? A literature overview. Transplantation 2000; 70: 711-6.

4. Messias E, Skotzko CE. Psychiatric assessment in transplantation. Rev Saúde Pública. 2000; 34: 415-20.

5. Trzepacz PT, Brenner R, Van Thiel DH. A psychiatric study of 247 liver transplantation candidates. Psychosomatics 1989; 30: 147-53.

6. Organização Mundial de Saúde. Classificação de Transtornos Mentais e de Comportamento da Cid-10: descrições clínicas e diretrizes diagnósticas. Porto Alegre: Artes Médicas; 1993.

7. Gorestein C, Andrade L. Inventário de depressão de Beck: propriedades psicométricas da versão em português. Rev Psiq Clin. 1998; 25: 245-50.

8. Singh N, Gayowski T, Wagener MM, Marino IR. Depression in patients with cirrhosis-impact on outcome. Dig Dis Sci. 1997; 42: 1421-7.

9. Di Martini A, Dew MA, Javed L, Fitzgerald MG, Jain A, Day N. Pretransplant psychiatric and medical comorbidity of alcoholic liver disease patients who received liver transplant. Psychosomatics 2004; 45: 517-23.

10. Norris ER, Smallwood GA, Connor K, Mcdonell K, Martinez E, Stieber AC, Heffron TG. Prevalence of depressive symptoms in patients being evaluated for liver transplantation. Transplant Proc. 2002; 34: 3285-6.

\section{Correspondence:}

Patrícia Duarte Martins

Hospital das Clínicas-Departamento de Neurologia, Psiquiatria e Psicologia Médica

FMRP-USP

CEP: 14049-990, Ribeirão Preto, SP, Brazil.

Email: patricia.dm@terra.com.br
Conflict of interest: none Financial source: none

\section{How to cite this article:}

Martins PD, Sankarankutty AK, Castro-e-Silva O, Gorayeb R. Psychological distress in patients listed for liver transplantation. Acta Cir Bras. [serial on the Internet] 2006;21 Suppl 1. Available from URL: $\underline{\text { http://www.scielo.br/acb }}$ 